\title{
Effect of nickel content on the anodic dissolution and passivation of zinc-nickel alloys in alkaline solutions by potentiodynamic and potentiostatic techniques
}

\author{
ABDEL-RAHMAN EL-SAYED, HANY M ABD EL-LATEEF* and HOSSNIA S MOHRAN \\ Chemistry Department, Faculty of Science, Sohag University, Sohag 82524, Egypt
}

\begin{abstract}
The effect of systematic increase of $\mathrm{Ni}$ on the anodic dissolution and passivation of $\mathrm{Zn}-\mathrm{Ni}$ alloys in various concentrations of $\mathrm{KOH}$ solution (0.1-1 M) was investigated. The anodic dissolution and passivation behaviour for each pure $\mathrm{Zn}$ and $\mathrm{Ni}$ in the same studied solutions was also investigated, and the obtained data were compared. Potentiodynamic and potentiostatic methods were used, and the corrosion layer formed on each electrode surface was characterized by X-ray diffraction (XRD) and scanning electron microscope (SEM). The results of the anodic potentiodynamic measurements exhibited that the polarization curves showed active/passive transition in the case of $\mathrm{Ni}$ and active/pseudopassive in the case of both $\mathrm{Zn}$ and its alloys. The results showed that the increase in Ni content increases the activation energy $\left(E_{\mathrm{a}}\right)$ and decreases the dissolution rate of the alloys in $\mathrm{KOH}$ solution, and the lowest dissolution rate was obtained at $10 \% \mathrm{Ni}$. The results of both potentiodynamic and potentiostatic measurements exhibit sudden increase in current density which is observed at certain positive potential $(+0.42 \mathrm{~V}$ vs. SCE) in the case of the investigated alloys. This indicates that the addition of $\mathrm{Ni}$ to $\mathrm{Zn}$ promotes the electrochemical reaction (in the passive region). However, the passivation potential shifted to more positive direction with the increase in Ni content in the alloy.
\end{abstract}

Keywords. Metal; alloys; anodic dissolution; passivation; electron microscopy; X-ray diffraction.

\section{Introduction}

Zinc is preferred to other anode materials both in chloride and alkaline primary batteries, owing to its electrochemical and ecological merits. ${ }^{1}$ The latter find increasing use as sources of energy in various electronic devices. However, the observed tendency of zinc to corrode during storage of batteries remains the most difficult problem. Hence its electrochemical properties in alkaline solution are under active investigation. ${ }^{2-22}$ It is well known that the process of zinc dissolution in alkaline media is responsible for the formation of a layer of mixed oxide and hydroxide on its surface. Nickel and nickel alloys are important materials for the design vessels in different process industries. ${ }^{23}$ Nickel electrode is also used in different energy-producing cells in which aqueous or non-aqueous solutions are used as electrolytes. Nickel and its alloys exhibited excellent corrosion resistance in aqueous aggressive environments, which are attributed to the ability of nickel to form a stable passive film on its surface. ${ }^{24-33}$

In recent years, several attempts have been made at preparing zinc coating with high corrosion resistance. In so doing, zinc alloys with the group 8 metals have been developed, ${ }^{34-39}$ and, among these, zinc-nickel alloys have received most

\footnotetext{
*Author for correspondence (Hany_shubra@yahoo.co.uk)
}

attention because of their high degree of corrosion resistance and their mechanical properties. In spite of the appearance of so many publications on the electrochemical behaviour of $\mathrm{Zn}-\mathrm{Ni}$ alloy electrodeposition in aqueous solutions, but very little work on the corrosion behaviour of the synthetic $\mathrm{Zn}-\mathrm{Ni}$ alloy (by fusion) has been reported in our previous work. ${ }^{40}$ In continuation of the previous studies, the present work concerns with the effect of $\mathrm{Ni}$ on the anodic behaviour and passivation of $\mathrm{Zn}-\mathrm{Ni}$ alloy in alkaline solutions following potentiodynamic and potentiostatic techniques.

In this work, anodic polarization of the investigated electrodes in various concentrations of $\mathrm{KOH}$ solution using both potentiodynamic and potentiostatic measurements was studied. The role of both Ni content and temperature on the corrosion and passivation behaviour of the alloys was examined. X-ray diffraction (XRD) and scanning electron microscope (SEM) were used for the characterization of the corrosion layer formed on all investigated electrodes surfaces, under their anodic polarization in the examined solution.

\section{Experimental}

\subsection{Materials and solutions}

Solutions of KOH (analytical grade) were prepared by dissolving the appropriate weight in doubly distilled water. 
Zn and Ni of high purity (99.999\%; Johnson Matthey Chemicals Ltd.) were used to prepare $\mathrm{Zn}-\mathrm{Ni}$ alloy as disk electrodes $\left(A=0.196 \mathrm{~cm}^{2}\right)$ in a Gallenkamp muffle furnace using evacuated closed silica tubes with the dimension $10 \times 1 \mathrm{~cm}^{2}$ up to $1173 \mathrm{~K}\left(900^{\circ} \mathrm{C}\right)$ for $24 \mathrm{~h}$ according to the phase diagram of $\mathrm{Zn}-\mathrm{Ni}$ system, has been considered by Okamoto. ${ }^{41}$ The melts were shaken every $6 \mathrm{~h}$ to ensure the homogeneity of melting alloys. The details of the preparation method and identification of the synthetic alloys were mentioned in our previous work. ${ }^{40}$ The prepared alloys were analysed using X-ray photoelectron spectroscopy. For the alloys, the percentages of $\mathrm{Zn}$ and $\mathrm{Ni}$ were found in accordance with the percentage of mixing $\mathrm{Zn}$ and $\mathrm{Ni}$.

\subsection{Electrochemical measurements}

The measurements were performed on planar disk electrode embedded in an Araldite holder. Before each experiment, the surfaces of the working electrodes were polished using polishing cloth (polishing machine; Buehler, Lake Bluff, Illinois, USA), until their surfaces became smooth and mirror-like bright. Then degreased in pure ethanol and washed in running bidistilled water before being inserted in the polarization cell. The reference electrode was a saturated calomel electrode (SCE) to which all potentials are referred.

The cell description is given elsewhere. ${ }^{42}$ To remove any surface contamination and air formed oxide, the working electrode was kept at $-1.50 \mathrm{~V}$ vs. SCE for $5 \mathrm{~min}$ in the tested solution, disconnected, shaken free of adsorbed hydrogen bubbles and anodic polarization was recorded. Potentiostat/Galvanostat (EG\&G Model 273) connected with a personal computer (IBM Model 30) was used for the measurements.

2.2a Potentiodynamic technique: The potentiodynamic polarization studies were carried out with electrodes having a surface area of $0.196 \mathrm{~cm}^{2}$. The potential was altered automatically from the steady state of open-circuit potential ( $\left.E_{\text {corr }}\right)$ up to positive potentials $v s$. SCE and at scan rate of $1 \mathrm{mV} \mathrm{s}^{-1}$ using software version 342C Supplied from EG\&G Princeton Applied Research.

2.2b Potentiostatic technique: The anodic potential was fixed at a required constant value and the variation of current density was recorded as a function of time (current density-time transients).

\subsection{Surface characterization}

The composition of the corrosion layer formed on each electrode surface was investigated by XRD, using a diffractometer with an iron filter and copper radiation was used with an accelerating voltage of $30 \mathrm{kV}$ and a filament current of $20 \mathrm{~mA}$. The morphology of the corrosion layer formed on each electrode was also examined using SEM (JEOL, model 5300).
Each experiment was performed with freshly prepared solutions and clean set of electrodes. Measurements were conducted at 298, 308, 318 and $328 \mathrm{~K}(25,35,45$ and $55 \pm$ $0.5^{\circ} \mathrm{C}$ ) for each investigated electrode. For this purpose ultrathermostat model Frigiter 6000382 (SELECTA) was used.

\section{Results and discussion}

\subsection{Potentiodynamic measurements}

3.1a Behaviour of zinc: Figure 1 shows the potentiodynamic polarization curves for zinc anode in various concentrations of $\mathrm{KOH}$ solution $(0.25-1.0 \mathrm{M})$ at scan rate $1 \mathrm{mV} \mathrm{s}^{-1}$ and $25^{\circ} \mathrm{C}$. The polarization curves were swept from steady state of open-circuit potential $\left(E_{\text {corr }}\right)$ up to $0.0 \mathrm{~V}$ (SCE). The data revealed that the anodic polarization curves exhibit active/pseudopassive transition. The active dissolution region involves two small anodic peaks $\left(\mathrm{A}_{\mathrm{I}}\right.$ and $\left.\mathrm{A}_{\mathrm{II}}\right)$, followed by a passive region which extends up to $0.0 \mathrm{~V}$ (SCE) with slightly increase in the passive current density $\left(I_{\text {pass }}\right)$. The first anodic peak $\mathrm{A}_{\mathrm{I}}$ is located at about $-1.382 \mathrm{~V}$ (SCE) in $0.25 \mathrm{M} \mathrm{KOH}$ solution, which can be associated with active oxidation of $\mathrm{Zn}$ under the experimental conditions could be explained based upon the reaction ${ }^{43}$

$$
\mathrm{Zn}+2 \mathrm{OH}^{-} \rightarrow \mathrm{Zn}(\mathrm{OH})_{2}+2 \mathrm{e}^{-} .
$$

The second anodic peak $A_{\mathrm{II}}$ located at about $-1.229 \mathrm{~V}$ (SCE), corresponds to the dehydration of thermodynamically unstable $\mathrm{Zn}(\mathrm{OH})_{2}$ to the corresponding stable $\mathrm{ZnO}$ occurring on zinc surface during the potential sweep to the positive direction:

$$
\mathrm{Zn}(\mathrm{OH})_{2} \rightarrow \mathrm{ZnO}+\mathrm{H}_{2} \mathrm{O}
$$

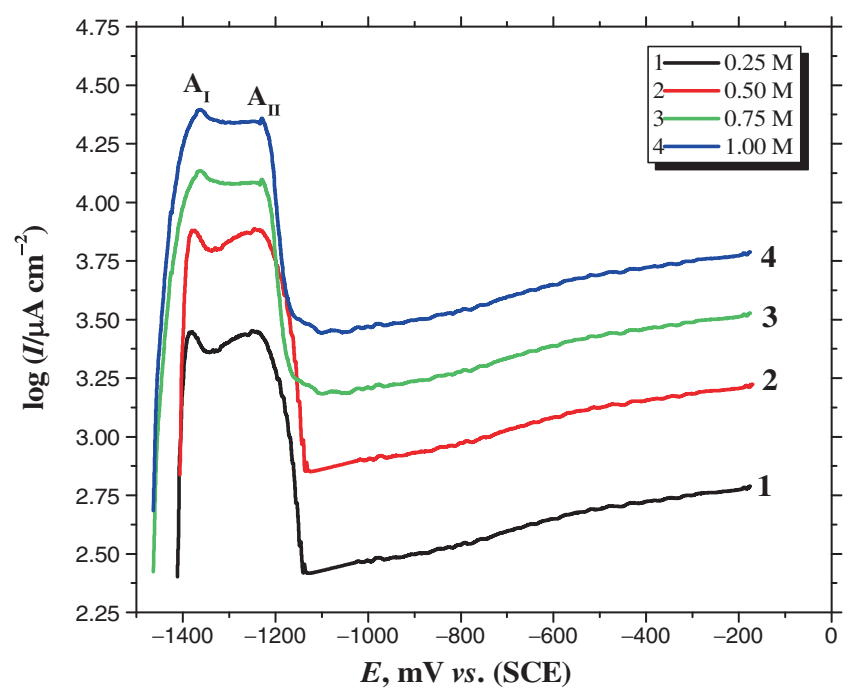

Figure 1. Potentiodynamic anodic polarization curves for pure $\mathrm{Zn}$ in various concentrations of $\mathrm{KOH}$ solution at $298 \mathrm{~K}\left(25^{\circ} \mathrm{C}\right)$. 
Further increase of potential in the positive direction leads to the formation of $\mathrm{ZnO}_{2}$ according to

$$
\mathrm{ZnO}+2 \mathrm{OH}^{-} \rightarrow \mathrm{ZnO}_{2}+\mathrm{H}_{2} \mathrm{O}+2 \mathrm{e} .
$$

Shams El Din et $a l^{44}$ and Popova et $a l^{45}$ observed that $\mathrm{ZnO}_{2}$ is formed in weak alkaline media only or closely to the oxygen evolution potential. When the surface is covered with the passive film, the dissolution current falls to small value $\left(I_{\text {pass }}\right)$, indicating the onset of permanent passivation. However, with the increase in the potential in the positive direction the current density of passivation gradually increases. This behaviour may be attributed to dissolution of some $\mathrm{ZnO}$ or $\mathrm{Zn}(\mathrm{OH})_{2}$ on the $\mathrm{Zn}$ surface. ${ }^{46}$

The obtained data reveal that an increase in the concentration of $\mathrm{KOH}$ solution results in an increase in both the peak currents and passivation current density $\left(I_{\text {pass }}\right)$, such behaviour was related to the decrease of $\mathrm{Zn}(\mathrm{OH})_{2}$ or $\mathrm{ZnO}$ and $\mathrm{ZnO}_{2}$ formed on the surface, with an increase of concentration. This was explained on the basis of the increase of the partial dissolution of oxide or hydroxide film with the increase concentration of $\mathrm{KOH}$. On the other hand, the data exhibited that the peaks potential $\left(\mathrm{A}_{\mathrm{I}}\right.$ and $\left.\mathrm{A}_{\mathrm{II}}\right)$ shift to more positive direction with increasing concentration. However, it is observed that the peak $\left(A_{I I}\right)$ is gradually reduced with the increase in concentration of $\mathrm{KOH}$, and disappears completely at highest concentration $(1 \mathrm{M})$. This behaviour may be attributed to the hindrance of the transformation of $\mathrm{Zn}(\mathrm{OH})_{2}$ (by dehydration) into $\mathrm{ZnO}$ or $\mathrm{ZnO}_{2}$ in higher concentration of $\mathrm{KOH}$ solution, particularly at the mentioned potential region of peak $\mathrm{A}_{\mathrm{II}}$. In addition, $\mathrm{ZnO}$ is dissolved by the reaction with further hydroxide to form the zincate ion $\left[\mathrm{Zn}(\mathrm{OH})_{4}\right]^{2-}$ according to the reaction ${ }^{46}$

$$
\mathrm{ZnO}+\mathrm{H}_{2} \mathrm{O}+2 \mathrm{OH}^{-} \rightarrow\left[\mathrm{Zn}(\mathrm{OH})_{4}\right]^{2-} .
$$

3.1b Behaviour of nickel: Figure 2 represents the potentiodynamic polarization curves for $\mathrm{Ni}$ electrode in various concentrations of $\mathrm{KOH}$ solution at scan rate $1 \mathrm{mV} \mathrm{s}^{-1}$ and $25^{\circ} \mathrm{C}$. The data revealed that the anodic excursion exhibits active/passive transition. The active dissolution region involves two anodic peaks $\left(\mathrm{A}_{\mathrm{I}}\right.$ and $\left.\mathrm{A}_{\mathrm{II}}\right)$ prior to the permanent passive region. The first anodic peak $A_{I}$ is located at about $-0.201 \mathrm{~V}(\mathrm{SCE})$ in $0.25 \mathrm{M} \mathrm{KOH}$ solution may correspond to the following reactions:

$$
\mathrm{Ni}+2 \mathrm{OH}^{-} \rightarrow \mathrm{HNiO}_{2}^{-}+\mathrm{H}^{+}+2 \mathrm{e}^{-}
$$

and/or

$$
\mathrm{Ni}+2 \mathrm{OH}^{-} \rightarrow \mathrm{Ni}(\mathrm{OH})_{2}+2 \mathrm{e}^{-}
$$

The formation of $\mathrm{HNiO}_{2}^{-}$may be considered as the starting process for the dissolution reaction. While the broad anodic peak $\mathrm{A}_{\mathrm{II}}$ appearing at about $+1.942 \mathrm{~V}$ vs. SCE is

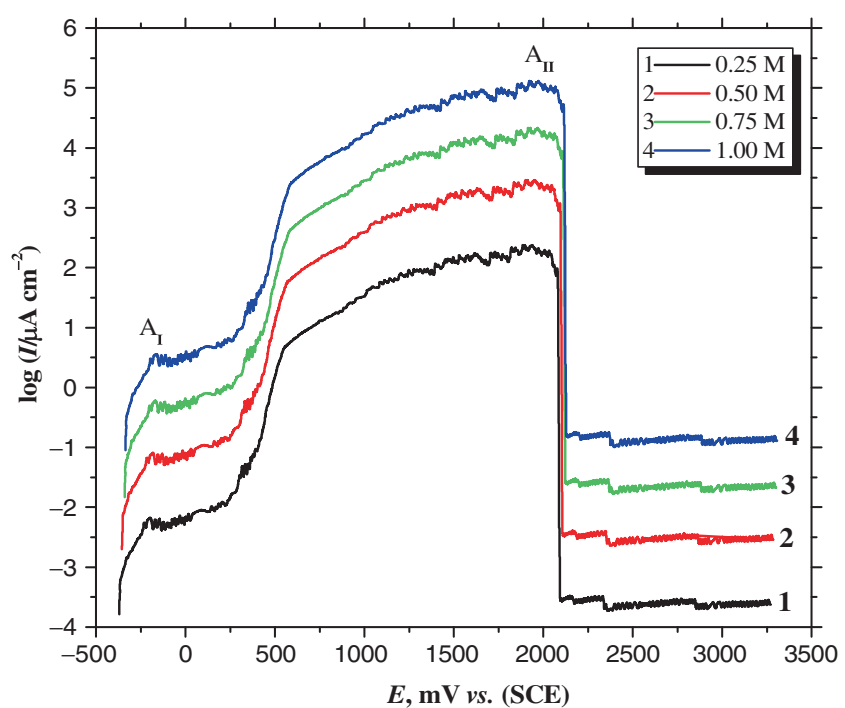

Figure 2. Potentiodynamic anodic polarization curves for pure $\mathrm{Ni}$ in various concentrations of $\mathrm{KOH}$ solution at $298 \mathrm{~K}\left(25^{\circ} \mathrm{C}\right)$.

related to direct oxidation of $\mathrm{Ni}$ into $\mathrm{NiO}$ according to the reaction

$$
\mathrm{Ni}+2 \mathrm{OH}^{-} \rightarrow \mathrm{NiO}+\mathrm{H}_{2} \mathrm{O}+2 \mathrm{e}^{-} .
$$

However, the broad anodic peak $\mathrm{A}_{\mathrm{II}}$ can be attributed to the competition between the anodic formation of the hydroxide or oxide and chemical dissolution of the passive oxide film on the Ni surface. ${ }^{24,25}$ When the surface is covered with the passive film, the dissolution current falls to very small value $\left(I_{\text {pass }}\right)$, indicating the onset of permanent passivation. The passive currents were estimated from anodic potentiodynamic polarization curves at the minimum current density (in passive region). It seems that the passive layer increases the overpotential for oxygen evolution. ${ }^{47}$ The current flowing through the passive region may correspond to the film formation and the replacement of chemically dissolved film materials. ${ }^{24,25}$ Previous works confirmed duplex nature of the passive film, which consists of both $\mathrm{Ni}(\mathrm{OH})_{2}$ and $\mathrm{NiO}{ }^{24,25}$ At the same time, during the positive going polarization of $\mathrm{Ni}$ in $\mathrm{KOH}$, transformation of $\mathrm{Ni}(\mathrm{OH})_{2}$ to $\beta-\mathrm{NiOOH}$ takes place. It has been suggested by the same authors that $\beta-\mathrm{Ni}(\mathrm{OH})_{2}$ can be oxidized to $\beta-\mathrm{NiOOH}$ at higher potential via a deprotonation reaction ${ }^{24}$

$$
\beta-\mathrm{Ni}(\mathrm{OH})_{2} \rightarrow \beta-\mathrm{NiOOH}+\mathrm{H}^{+}+\mathrm{e}^{-} .
$$

Confirmation of this reaction in a nickel-cadmium cell was made by $\mathrm{Uno}^{48}$ who showed, using X-ray measurements, that $\mathrm{Ni}(\mathrm{OH})_{2}$ indeed converts to the oxyhydroxide upon charging. The data also reveal that, peak current densities $A_{I}$ and $\mathrm{A}_{\mathrm{II}}$ of the two anodic peaks and passivation current density $\left(I_{\text {pass }}\right)$ increase with the increase in the alkali concentration. This behaviour could be ascribed to the increase of the chemical dissolution rate with the increase in the concentration of 
$\mathrm{KOH}$ solution. However, it is observed that the peak's potentials $E_{\mathrm{AI}}$ and $E_{\mathrm{AII}}$ seem to be not affected with the variation of $\mathrm{KOH}$ concentration.

3.1c Behaviour of $\mathrm{Zn}-\mathrm{Ni}$ alloys: Figure 3 shows the potentiodynamic $E / I$ curves of $\mathrm{Zn}-\mathrm{Ni}$ alloy IV (as a representative alloy) in various concentrations of $\mathrm{KOH}$ solution at $25^{\circ} \mathrm{C}$ and scan rate $1 \mathrm{mV} \mathrm{s}^{-1}$. The curves were swept from $E_{\text {corr }}$ up to positive potential $(+0.80 \mathrm{~V}$ vs. SCE). The polarization curves showed three active dissolution peaks, permanent passivation and finally breakdown of passive region. The three peaks $\left(\mathrm{A}_{\mathrm{I}}, \mathrm{A}_{\mathrm{II}}\right.$ and $\left.\mathrm{A}_{\mathrm{III}}\right)$ are well defined at about $-1.325,-1.20$ and $-0.888 \mathrm{~V}$ vs. SCE, respectively. However, the data reveal that the anodic current of peak III is higher than that of peak I or II.

In active dissolution region, firstly zinc in the alloy dissolves as $\left[\mathrm{Zn}(\mathrm{OH})_{4}\right]^{2-}$ ions as the following:

$$
\mathrm{Zn}+4 \mathrm{OH}^{-} \rightarrow\left[\mathrm{Zn}(\mathrm{OH})_{4}\right]^{2-}+2 \mathrm{e}^{-} .
$$

Further increase of potential in the positive direction leads to the formation of $\mathrm{Zn}(\mathrm{OH})_{2}$ and/or $\mathrm{ZnO}$ (peaks I and II). At the same time, during the positive going polarization electrode of alloy in $\mathrm{KOH}$ solution, the current density increases steadily with the potential to give peak III $(-0.888 \mathrm{~V} v s$. $\mathrm{SCE}$ ). This peak corresponds to simultaneous Ni dissolution on the alloy surface and oxide formation according to the reactions in eqs (7) and (8), respectively. Flowing the anodic peak, the electrode becomes passive and the current density decreases to lower values and extends over a wide potential range. The current flowing along this region is governed by the fixed rate of dissolution of the passivating film in the electrolyte. However, the film dissolution is counter balanced by film formation. ${ }^{47}$ This is indicating that the onset of passivation can be due to the precipitation of $\mathrm{ZnO} / \mathrm{ZnO}_{2}$ and $\mathrm{NiO}$ on the surface. In other words, this behaviour can be attributed to that the mentioned oxides block the

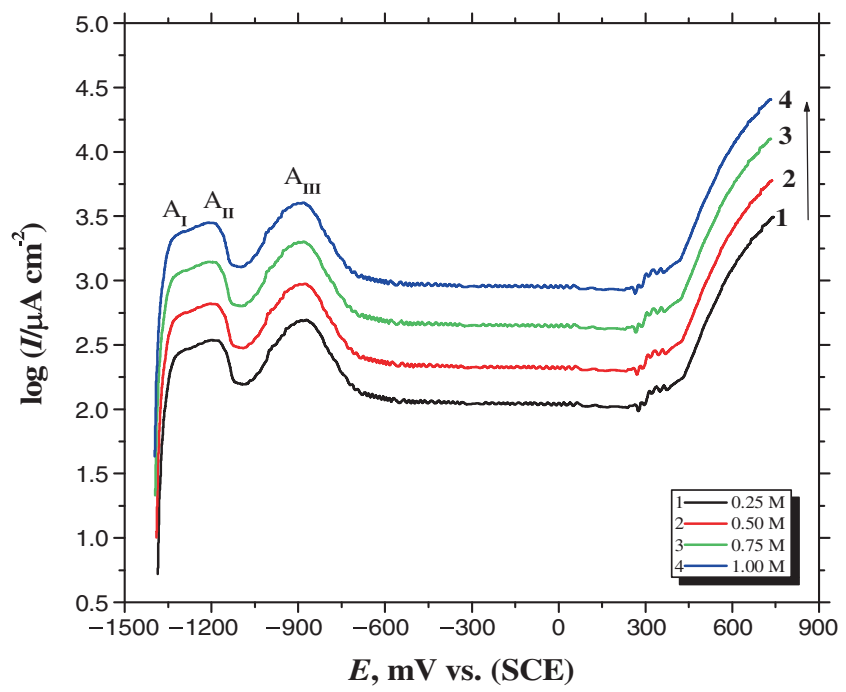

Figure 3. Potentiodynamic anodic polarization curves for alloy IV in various concentrations of $\mathrm{KOH}$ solution at $298 \mathrm{~K}\left(25^{\circ} \mathrm{C}\right)$. dissolution of the active sites and cause inactivation of a part of the surface towards the corrosive medium. ${ }^{49}$ This suggestion is supported by XRD which will be discussed later. On the other hand, the results revealed that by increasing $\mathrm{KOH}$ solution concentration, the anodic current peaks increase and the potential corresponding to these peaks are shifted to more positive direction. Also, the current density of both permanent passivation region and breakdown of oxide layer at certain potential $(+0.42 \mathrm{~V} v s$. SCE) is increased as an increase of the concentration of $\mathrm{KOH}$ solution. These results could be explained on the basis of the dissolving power of $\mathrm{OH}^{-}$ion on the layer formed by anodic treatment. ${ }^{40,50}$

Figure 4 shows comparison between the potentiodynamic polarization curves of $\mathrm{Zn}$ and the investigated alloys in $0.5 \mathrm{M}$ $\mathrm{KOH}$ solution at $25^{\circ} \mathrm{C}$. It was found that the current of two peaks in the case of $\mathrm{Zn}$ are higher than those of the investigated alloys. It is interesting to note that, the current of peaks $A_{I}$ and $A_{I I}$ gradually decreases while for peak $A_{I I I}$ increases with the increase in $\mathrm{Ni}$ content in the alloy (figure 5). This behaviour exhibits very important results that $\mathrm{Ni}$ content in the alloy plays an important role in decreasing the dissolution rate of zinc in alkaline solution. For alloy electrodes, the increase in Ni content (from 0.5 to $10 \%$ ) decreases both the anodic corrosion $\left(I_{\text {peak }}\right)$ and passivation current $\left(I_{\text {pass }}\right)$ of the alloy under the same conditions, hence improves its stability against corrosion. The peaks potentials $\left(\mathrm{A}_{\mathrm{I}}, \mathrm{A}_{\mathrm{II}}\right.$ and $A_{\text {III }}$ ) (the data not present here) shift to more positive direction as an increase Ni content. This behaviour confirms that the tendency of the alloy towards passivity is delayed, while the corrosion resistance of alloy increases with $\mathrm{Ni}$ content. Accordingly, the results show the corrosion resistance of $\mathrm{Zn}-\mathrm{Ni}$ alloy is superior to that of $\mathrm{Zn}$ in alkaline solutions, and $10 \% \mathrm{Ni}$ alloy gives higher corrosion resistance. ${ }^{36}$ The superior corrosion resistance observed for the investigated $\mathrm{Zn}-\mathrm{Ni}$ alloys compared with that of $\mathrm{Zn}$ could be explained

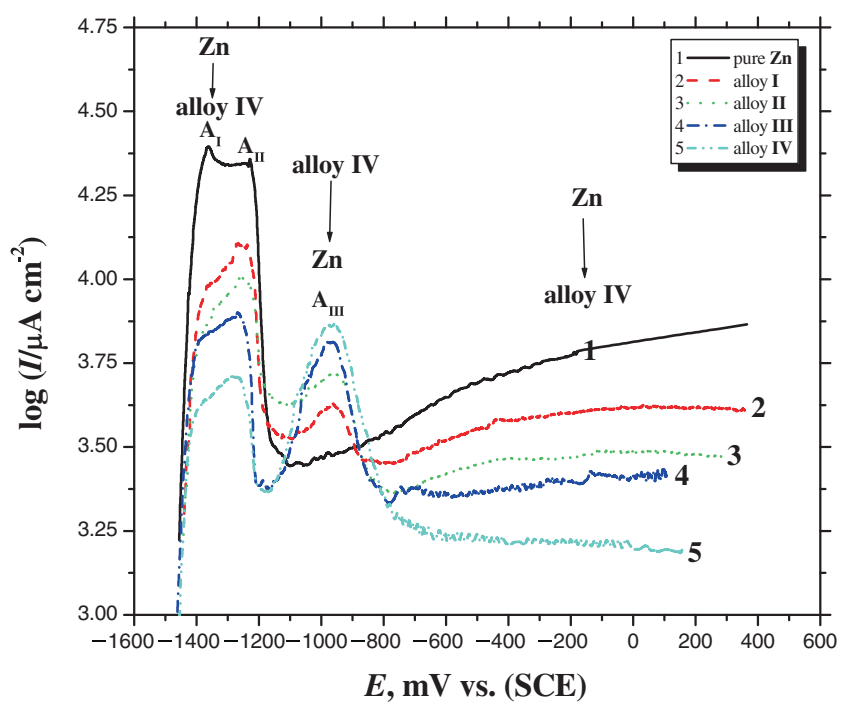

Figure 4. Comparison between potentiodynamic anodic polarization curves for $\mathrm{Zn}$ and $\mathrm{Zn}-\mathrm{Ni}$ alloys in $0.5 \mathrm{M}$ solution of $\mathrm{KOH}$ at $298 \mathrm{~K}\left(25^{\circ} \mathrm{C}\right)$. 


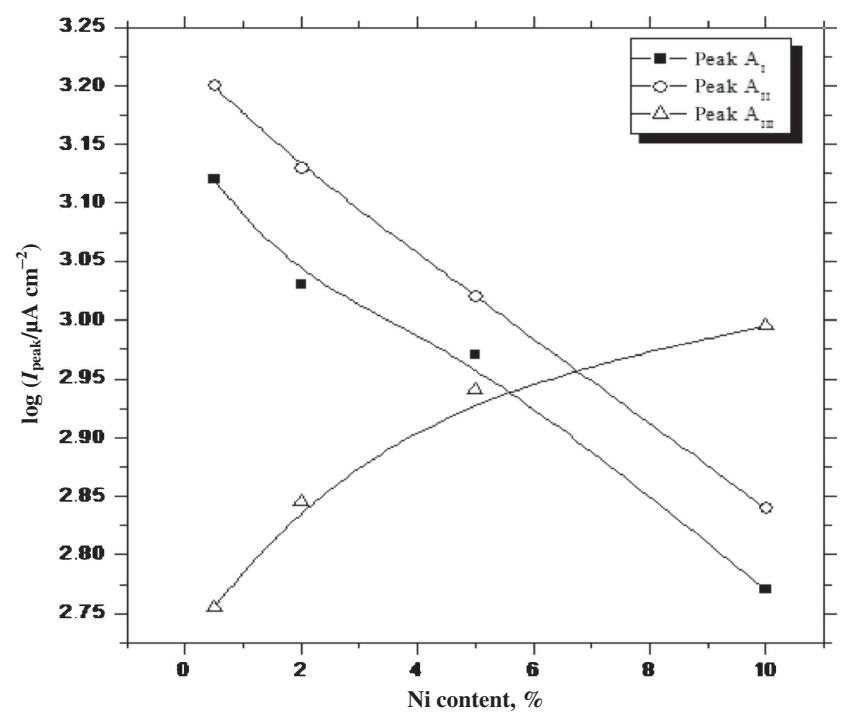

Figure 5. Dependence of the peaks current density $I_{\text {peak }}$ on $\mathrm{Ni}$ content in the alloy in $0.50 \mathrm{M} \mathrm{KOH}$ solution at $298 \mathrm{~K}\left(25^{\circ} \mathrm{C}\right)$.

by the barrier protection mechanism theory during acts as a barrier to further attack. This behaviour can be attributed to the presence of single $\gamma$-phase structure and hence the absence of local cells between different phases. In addition, the presence of $\mathrm{Ni}$ in the alloy shows slow down the dehydration of $\mathrm{Zn}(\mathrm{OH})_{2}$ (as a product of corrosion) to $\mathrm{ZnO}$. The hydroxide has a lower level of electronic conductivity than the oxide; therefore the corrosion is slower. ${ }^{51}$ However, it is observed that, the values of passive current in the case of the investigated alloys are higher than that of pure $\mathrm{Ni}$ under the same conditions. This behaviour could be attributed to the solubility of some $\mathrm{Zn}$ oxides or hydroxide film on the surface in $\mathrm{KOH}$ solution with shift the potential to more positive direction, which in turn, decreased the thickness of the film.

3.1d Effect of temperature: Figure 6 represents the potentiodynamic polarization curves for alloy IV in $0.5 \mathrm{M} \mathrm{KOH}$ solution at different temperatures. It can be seen that the temperature enhanced peaks $\mathrm{A}_{\mathrm{I}}, \mathrm{A}_{\mathrm{II}}$ and $\mathrm{A}_{\mathrm{III}}$ of alloy $\mathbf{I V}$ towards higher current densities, and shifted $\left(E_{\mathrm{p}}\right)_{\mathrm{AI}},\left(E_{\mathrm{p}}\right)_{\mathrm{AII}}$ and $\left(E_{\mathrm{p}}\right)_{\mathrm{AIII}}$ towards more positive values. On the other hand, the passivation current density increases also with the increase in the temperature. Similar effect of temperature in the case of pure zinc or nickel is observed to that mentioned of alloy IV. This indicates that an increase in temperature accelerates the rate of diffusion and migration of the reactant and product species, ${ }^{52}$ and consequently the corrosion reactions and the dissolution of oxide film.

Table 1 shows the values of the apparent activation energy $\left(E_{\mathrm{a}}\right)$ values for $\mathrm{Zn}$ and its investigated alloys in $0.5 \mathrm{M} \mathrm{KOH}$ solution at both peak $\mathrm{A}_{\mathrm{II}}$ and passivation current (at $0.2 \mathrm{~V}$ $v s$. SCE). These values are determined from the slope of Arrhenius plots ( $\log I_{\text {peak }}$ or $\log I_{\text {pass }} v s .1 / T$ plots) as shown in figures 7 and 8 applying the equation

$$
\log I=\log A-\frac{E_{\mathrm{a}}}{2 \cdot 33 R} \frac{1}{T}
$$

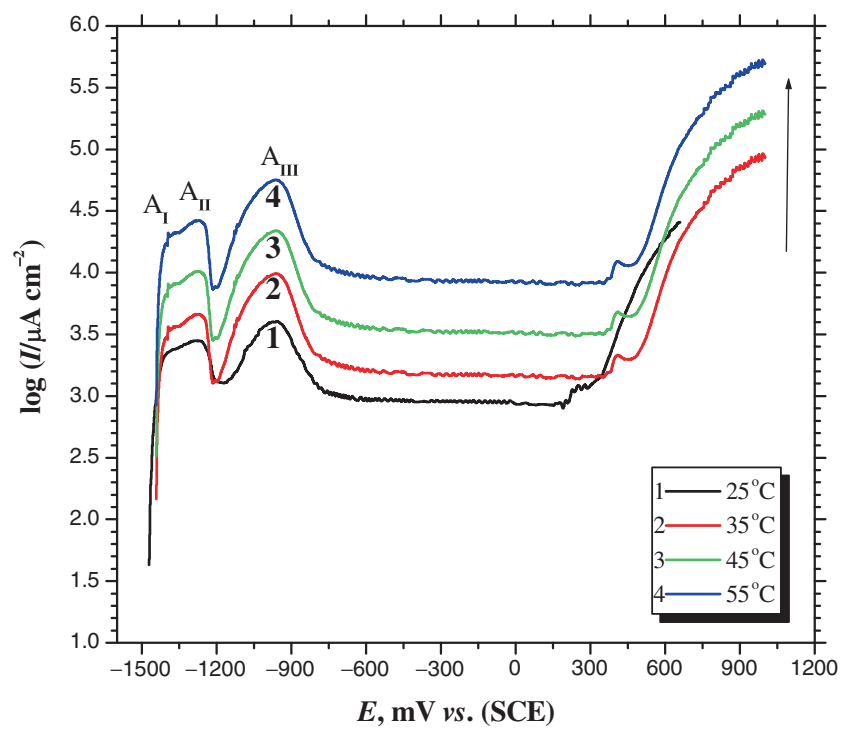

Figure 6. Potentiodynamic anodic polarization curves for alloy IV in $0.50 \mathrm{M}$ solution of $\mathrm{KOH}$ at different temperatures $\left(25-55^{\circ} \mathrm{C}\right)$.

Table 1. Apparent activation energy in $\mathrm{kJ} \mathrm{mol}^{-1}$ of $\mathrm{Zn}$ and $\mathrm{Zn}-\mathrm{Ni}$ alloys in $0.50 \mathrm{M} \mathrm{KOH}$ solution.

\begin{tabular}{|c|c|c|}
\hline $\begin{array}{l}\text { Metal } \\
\text { and alloy }\end{array}$ & $\begin{array}{c}E_{\mathrm{a}}\left(\mathrm{kJ} \mathrm{mol}^{-1}\right) \\
I_{\mathrm{p}} \text { vs. } 1 / T \\
\left(\text { at peak } \mathrm{A}_{\mathrm{II}}\right)\end{array}$ & $\begin{array}{c}E_{\mathrm{a}}\left(\mathrm{kJ} \mathrm{mol}^{-1}\right) \\
I_{\text {pass }} v s .1 / T \\
\text { (at } E=0.20 \mathrm{~V} v s . \mathrm{SCE})\end{array}$ \\
\hline $\mathrm{Zn}$ & 23.04 & 21.2 \\
\hline Alloy I $(0.5 \% \mathrm{Ni})$ & 32.16 & 29.54 \\
\hline Alloy II (2.0\% Ni) & 35.35 & 31.23 \\
\hline Alloy III (5.0\% Ni) & 37.97 & 33.26 \\
\hline Alloy IV (10.0\% Ni) & 44.45 & 40.81 \\
\hline
\end{tabular}

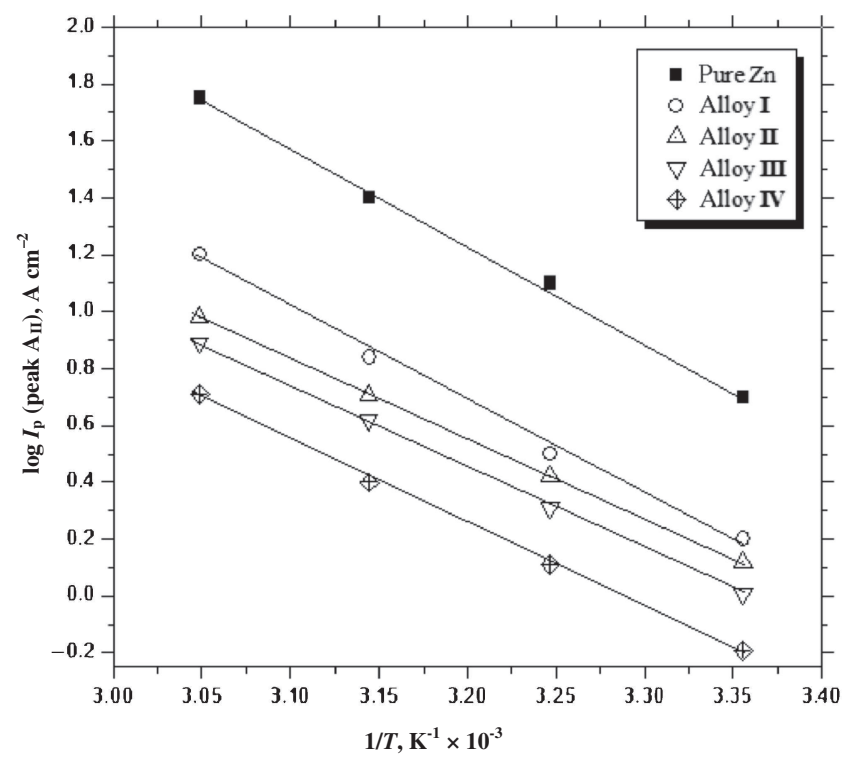

Figure 7. Arrhenius plots for $\mathrm{Zn}$ and $\mathrm{Zn}-\mathrm{Ni}$ alloys corrosion in $0.50 \mathrm{M}$ solution of $\mathrm{KOH}\left(\log I_{\text {peak }}\left(\mathrm{A}_{\mathrm{II}}\right)\right.$ vs. $\left.1 / T\right)$. 


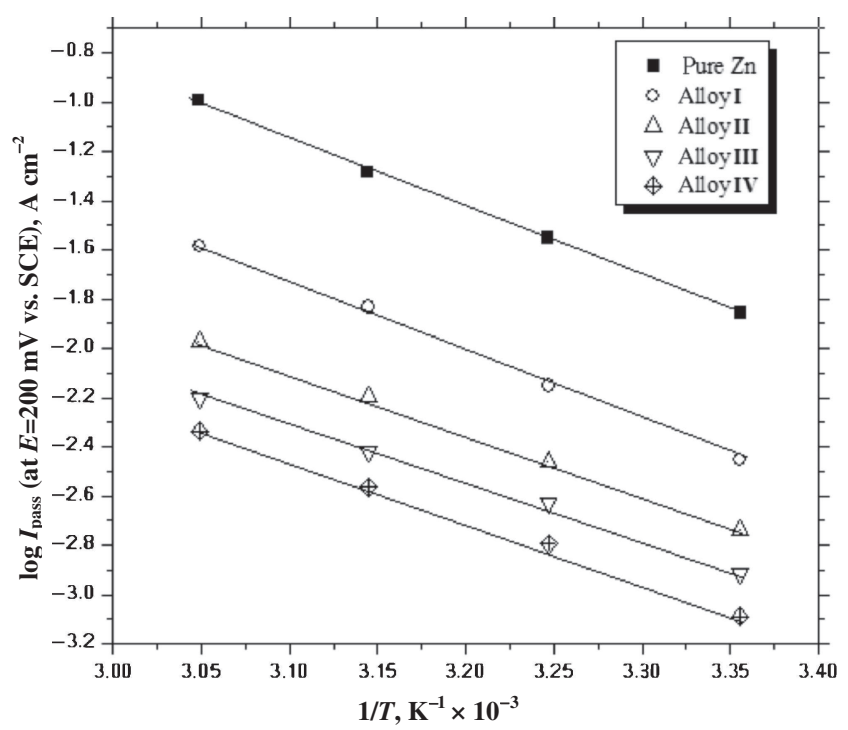

Figure 8. Arrhenius plots for $\mathrm{Zn}$ and $\mathrm{Zn}-\mathrm{Ni}$ alloys corrosion in $0.50 \mathrm{M}$ solution of $\mathrm{KOH}\left(\log I_{\text {pass }}\right.$ vs. $\left.1 / T\right)$.

where $I$ is the peak current or passivation current, $A$ the frequency factor, $E_{\mathrm{a}}$ the activation energy and $T$ the absolute temperature. It can be observed that the values of $E_{\mathrm{a}}$ gradually increases with the increase in the $\mathrm{Ni}$ content in the alloy, and the maximum value is obtained in the case of alloy IV at both peak and passivation current densities. This provides that the activation energy increases with the increase in the Ni content in alloy. This observed higher energy barrier would be attributed to the hindrance of dissolution process by increasing Ni content in the alloy. ${ }^{49}$ These data support our suggestion that the corrosion resistance of $\mathrm{Zn}-\mathrm{Ni}$ alloy in $\mathrm{KOH}$ solution increases with the increase in the $\mathrm{Ni}$ content.

\subsection{Potentiostatic measurements}

Figure 9a-c shows the current-time transient curves of $\mathrm{Zn}, \mathrm{Ni}$ and alloy $\mathbf{I V}$ in $0.5 \mathrm{M} \mathrm{KOH}$ solution at different applied anodic potentials and at $25^{\circ} \mathrm{C}$. It is observed that the current density decreases with time (except in the case of alloy IV at certain positive potential) at different applied potentials. The results show clearly that the currents measured of the investigated electrodes in the examined solution at more positive potentials are significantly reduced in comparison with the currents obtained at more negative potentials. This behaviour confirms that the tendency of the investigated electrodes towards passivity increases with shifting applied potential to more positive direction. However, in the case of alloy IV, it is observed that the current density $v s$. time at certain positive potential $(+0.42 \mathrm{~V} v s$. SCE) gives opposite behaviour to that observed for pure $\mathrm{Zn}$ and $\mathrm{Ni}$. That is, after certain time of immersed alloy IV in $0.5 \mathrm{M} \mathrm{KOH}$ solution, the current density rises suddenly. This exhibits that the oxide film formed on the alloy surface tends to breakdown, and reactivation of the alloy surface takes place at certain positive potential. ${ }^{53}$ This observation means that

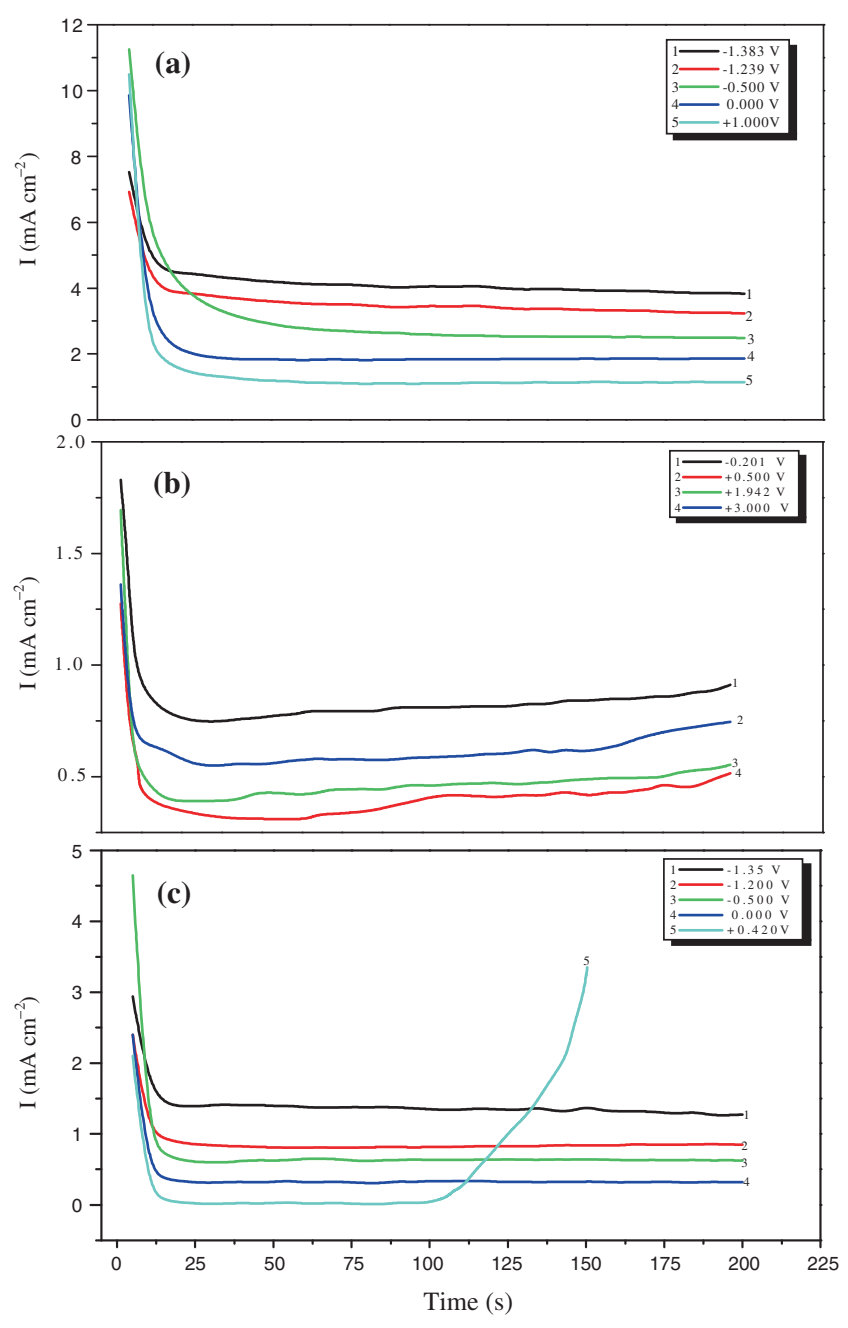

Figure 9. Potentiostatic transient's current $v s$. time curves for (a) pure $\mathrm{Zn}$, (b) pure $\mathrm{Ni}$ and (c) alloy IV in $0.50 \mathrm{M} \mathrm{KOH}$ solution at different applied potentials.

the passive layer on the alloy surface is destroyed and initiation of corrosion is occurred, where the metal oxides $\left(M_{x} \mathrm{O}_{y}\right)$ may be dissolved into $M^{\mathrm{n}+}\left(M=\mathrm{Zn}^{-1}\right.$ and/or Ni) in solution. ${ }^{54}$ Sato and Okamoto ${ }^{55}$ attributed the dissolution of oxide film to the presence of active patches in the passive oxide layer. We proposed that the reason why the passive film formed on the alloy surface has ability to breakdown at certain positive potential in $0.5 \mathrm{M} \mathrm{KOH}$ solution, as due to that some $\mathrm{Ni}(\mathrm{II})$ is precipitated in $\mathrm{ZnO}$ lattice. ${ }^{56}$ Such behaviour can be explained by the interaction between $\mathrm{OH}^{-}$ and $\mathrm{Ni}$ (II) which is precipitated in $\mathrm{ZnO}$ lattice. This interaction enhances the rate of diffusion of metal ions from the metal/film interface to the film/solution interface leading to the formation of cation vacancies, which lead in turn to breakdown of the passive film. ${ }^{57} \mathrm{~A}$ similar behaviour for the other investigated alloys (I-III) under the same conditions (the data are not presented here) is observed. The same breakdown potential of oxide film on the alloy $\mathbf{I}(0.5 \% \mathrm{Ni})$ in high concentration of $\mathrm{KOH}(7 \mathrm{M})$ was obtained by the authors. ${ }^{58}$ This behaviour indicates that reactivation of the alloy surface takes place in the passivation region. 


\subsection{Structures and properties of anodic passive film}

3.3a X-ray diffraction: The composition of the corrosion layer formed on the surfaces of $\mathrm{Zn}, \mathrm{Ni}$ and $\mathrm{Zn}-\mathrm{Ni}$ alloys after anodic potentiostatic polarization treatment in $0.5 \mathrm{M}$ $\mathrm{KOH}$ solution for $20 \mathrm{~min}$ at different formation potentials was examined. The passive electrode was withdrawn carefully, washed with doubly distilled water, dried and finally examined by XRD. Figure 10a represents XRD of the corrosion layer formed at peak potential of $\mathrm{Zn}$ electrode for peak $\mathrm{A}_{\mathrm{I}}(-1.382 \mathrm{~V}$ vs. SCE) in $0.5 \mathrm{M} \mathrm{KOH}$. The data confirm the existence of $\mathrm{Zn}$ as a major, but $\mathrm{Zn}(\mathrm{OH})_{2}$ and $\mathrm{ZnO}$ as minor constituents. These results indicate that the peak potential of zinc in $\mathrm{KOH}$ solution is related to the formation of $\mathrm{Zn}(\mathrm{OH})_{2} / \mathrm{ZnO}$ system on the electrode surface. In addition, XRD data for peak $A_{I I}$ (at $-1.229 \mathrm{~V}$ (SCE); figure $10 \mathrm{~b}$ ), indicate that the surface contains small amounts of $\mathrm{ZnO} / \mathrm{ZnO}_{2}$. These data support our suggestion that peak $\mathrm{A}_{\mathrm{II}}$ of $\mathrm{Zn}$ is related to the formation of $\mathrm{ZnO}$ and traces from $\mathrm{ZnO}_{2}$ system on the electrode surface.

$\mathrm{X}$-ray data for Ni electrode, treated potentiostatically in $0.5 \mathrm{M} \mathrm{KOH}$ at first peak potential $\mathrm{A}_{\mathrm{I}}(-0.209 \mathrm{~V}$ (SCE); figure 11a), indicate that the surface contains $\mathrm{Ni}$ and
$\mathrm{Ni}(\mathrm{OH})_{2}$. This confirms that the first peak $\mathrm{A}_{\mathrm{I}}$ could be attributed to $\mathrm{Ni}(\mathrm{OH})_{2}$ formation on the $\mathrm{Ni}$ surface. However, the data for $\mathrm{Ni}$ electrode, treated at $+1.460 \mathrm{~V}$ vs. SCE (peak $\mathrm{A}_{\mathrm{II}}$; figure $11 \mathrm{~b}$ ), show that the surface contains large amount from $\mathrm{NiOOH}$ and small amount $\mathrm{Ni}(\mathrm{OH})_{2}$. This exhibits that the surface is completely covered by mixed oxides of $\mathrm{NiOOH} / \mathrm{Ni}(\mathrm{OH})_{2}$, and the amount of $\mathrm{NiOOH}$ is higher compared with that of $\mathrm{Ni}(\mathrm{OH})_{2}$ at this investigated peak potential. This result confirms that peak potential $\left(\mathrm{A}_{\mathrm{II}}\right)$ is related to the conversion of $\mathrm{Ni}(\mathrm{OH})_{2}$ to $\mathrm{NiOOH}$. While, the data obtained at $+3.50 \mathrm{~V} v s$. SCE (passive region; figure 11c) show the existence of a mixture of oxides as $\mathrm{NiOOH}, \mathrm{NiO}$ and $\mathrm{Ni}_{2} \mathrm{O}_{3}$. This indicates that $\mathrm{Ni}$ surface is completely covered by a thick film from oxides mixture $(\mathrm{NiOOH}, \mathrm{NiO}$ and $\mathrm{Ni}_{2} \mathrm{O}_{3}$ ). This behaviour can be attributed to the conversion of $\mathrm{NiOOH}$ to $\mathrm{Ni}_{2} \mathrm{O}_{3}$ according to the following equation:

$$
2 \mathrm{NiOOH} \rightarrow \mathrm{Ni}_{2} \mathrm{O}_{3}+\mathrm{H}_{2} \mathrm{O} \text {. }
$$

These data support our suggestion that the very small current density which is observed in the passive region of potentiodynamic measurements can be attributed to formation of
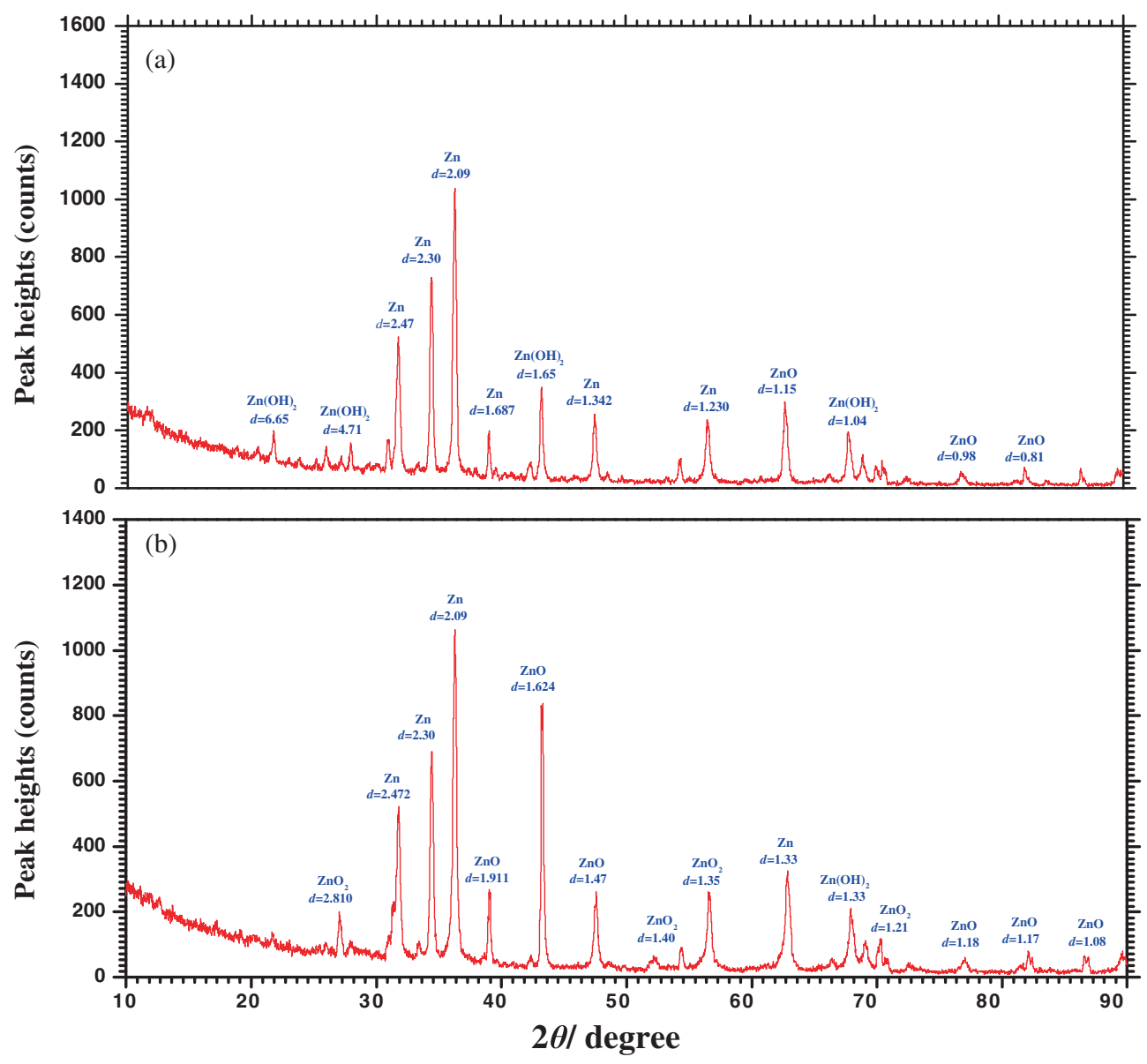

Figure 10. X-ray diffraction analysis for the corrosion layer on Zn electrode surface formed anodically in $0.50 \mathrm{M}$ solution of $\mathrm{KOH}$ at applied potential (a) $-1.382 \mathrm{~V}(\mathrm{SCE})$ peak $\mathrm{A}_{\mathrm{I}}$ and $(\mathbf{b})-1.229 \mathrm{~V}$ (SCE) peak $\mathrm{A}_{\mathrm{II}}$ and at $298 \mathrm{~K}\left(25^{\circ} \mathrm{C}\right)$. 

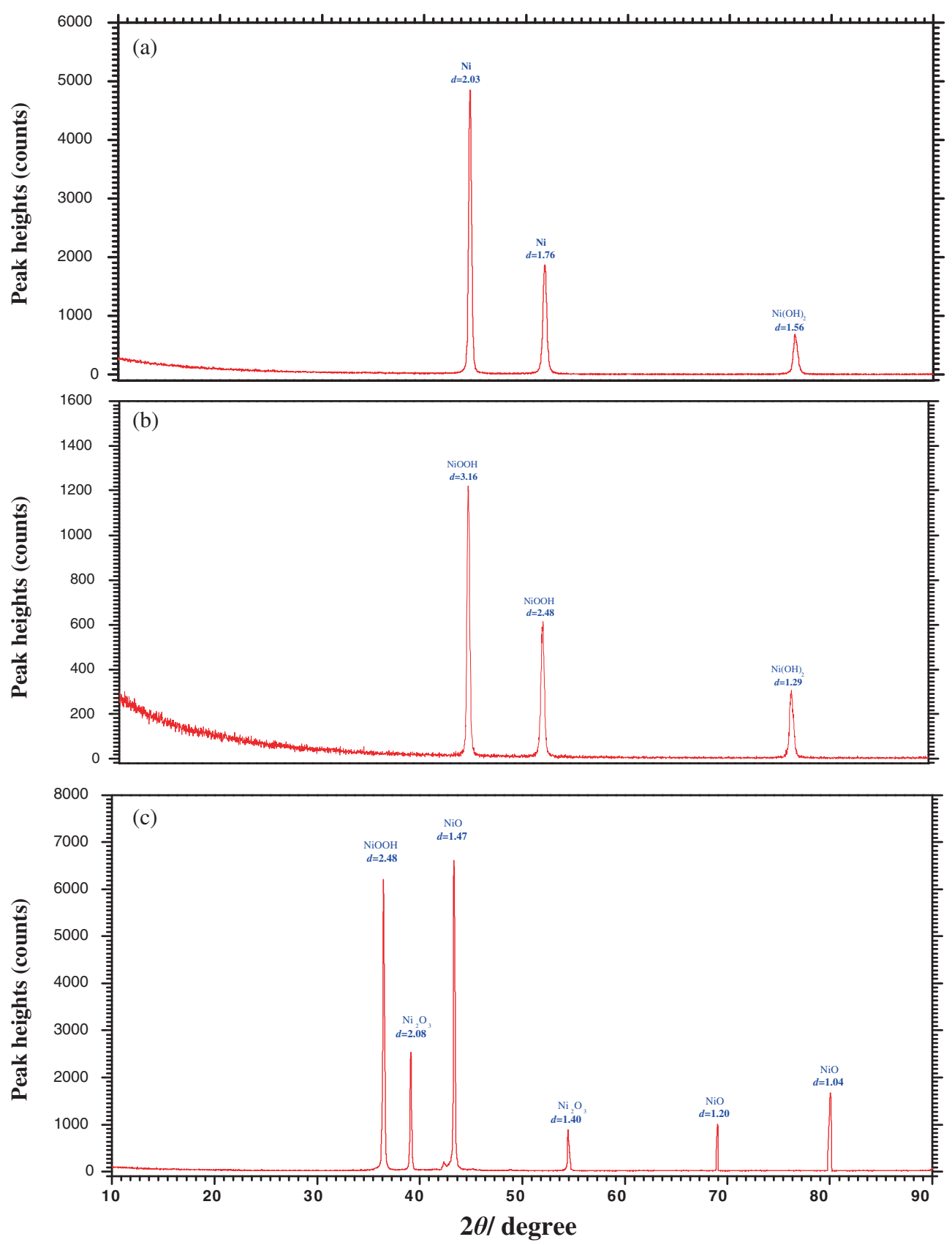

Figure 11. X-ray diffraction analysis for the corrosion layer on Ni electrode surface formed anodically in $0.50 \mathrm{M}$ solution of $\mathrm{KOH}$ at applied potential (a) $-0.209 \mathrm{~V}$ (SCE) peak $\mathrm{A}_{\mathrm{I}},(\mathbf{b})+1.460 \mathrm{~V}$ (SCE) peak $\mathrm{A}_{\mathrm{II}}$ and $(\mathbf{c})+3.50 \mathrm{~V}(\mathrm{SCE})$ passive region and at $298 \mathrm{~K}\left(25^{\circ} \mathrm{C}\right)$.

very thick oxide layer which covered the whole $\mathrm{Ni}$ surface. Therefore, there are not data obtained by XRD related to $\mathrm{Ni}$ metal at this region.

The data in figure 12a for the alloy IV treated potentiostatically at $-1.20 \mathrm{~V} v s$. SCE (peak $\mathrm{A}_{\mathrm{II}}$ ) in $0.5 \mathrm{M}$ $\mathrm{KOH}$ solution at $25^{\circ} \mathrm{C}$ reveal that the surface contains $\mathrm{Zn}, \gamma-\mathrm{Zn}_{3} \mathrm{Ni}$, and small amounts of $\mathrm{Zn}(\mathrm{OH})_{2}$ and $\mathrm{ZnO}$. This confirms that the data in figure 12a for the alloy IV treated potentiostatically at $-1.20 \mathrm{~V} v s$. SCE (peak $A_{\text {II }}$ ) in $0.5 \mathrm{M} \mathrm{KOH}$ solution at $25^{\circ} \mathrm{C}$ reveal that the surface contains $\mathrm{Zn}, \gamma-\mathrm{Zn}_{3} \mathrm{Ni}$, and small amounts of $\mathrm{Zn}(\mathrm{OH})_{2}$ and $\mathrm{ZnO}$.
This confirms that the peak potential at $-1.20 \mathrm{~V} v s$. SCE may be attributed to the formation of $\mathrm{Zn}(\mathrm{OH})_{2} / \mathrm{ZnO}$ on the alloy surface. This indicates that the alloy surface is partially covered by mixed film of $\mathrm{Zn}(\mathrm{OH})_{2}$ and $\mathrm{ZnO}$. However, the data of the same alloy, treated at $-0.888 \mathrm{~V} v s$. SCE (peak $\mathrm{A}_{\mathrm{III}}$; figure $12 \mathrm{~b}$ ), show that the surface contains small amounts of $\mathrm{Zn}$ and a large amounts of $\mathrm{Ni}(\mathrm{OH})_{2}$ and $\mathrm{ZnO}$ and small amount from $\mathrm{ZnO}_{2}$. Accordingly, the data reveal that the peak potential (peak $\mathrm{A}_{\text {III }}$ ) of alloy IV is related to the formation of $\mathrm{Ni}(\mathrm{OH})_{2} / \mathrm{NiO}$ and $\mathrm{ZnO} / \mathrm{ZnO}_{2}$ on the electrode surface. These results support our suggestion that the 

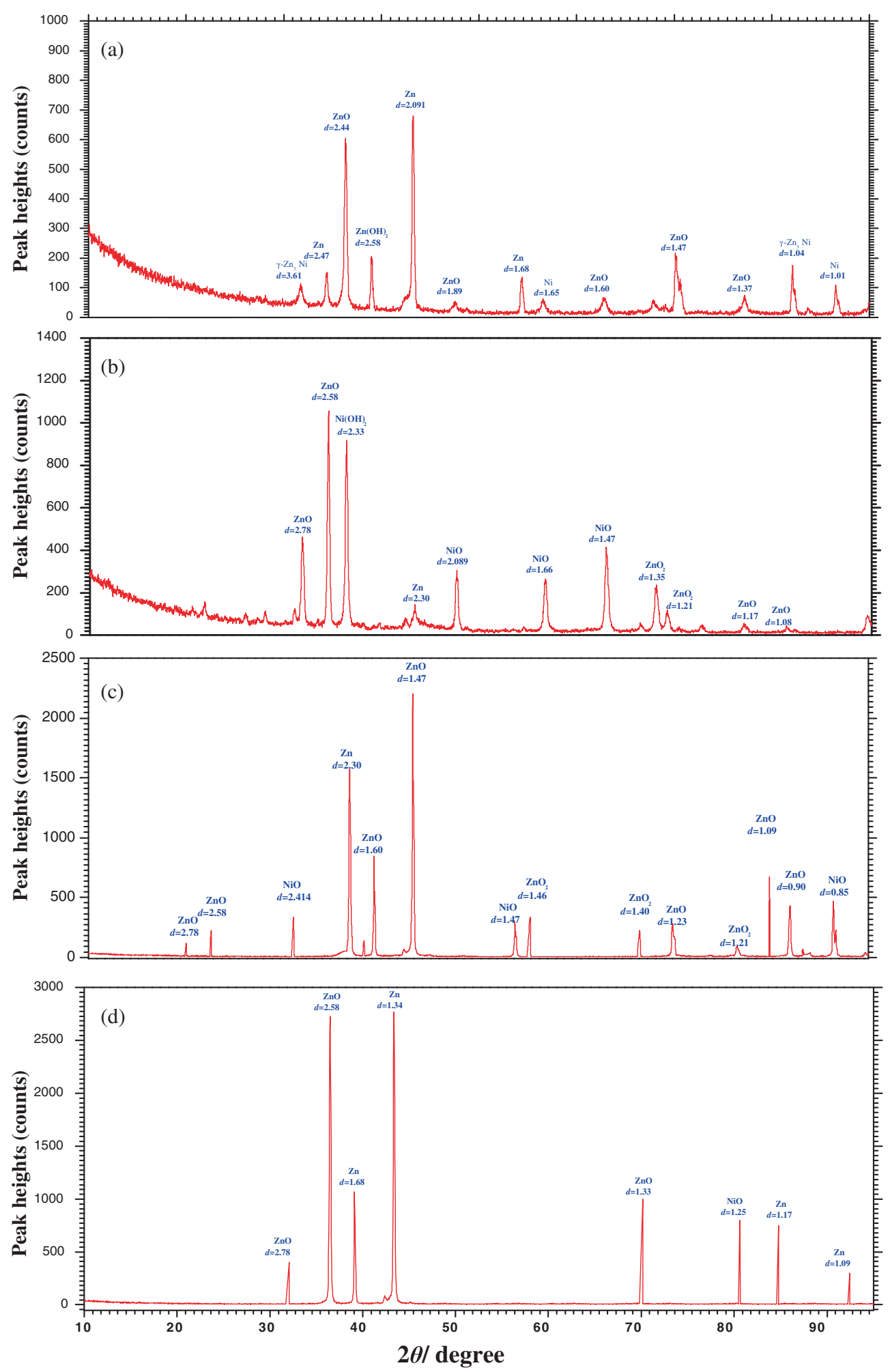

Figure 12. X-ray diffraction analysis for the corrosion layer on alloy IV surface formed anodically in $0.50 \mathrm{M}$ solution of $\mathrm{KOH}$ at applied potential (a) $-1.20 \mathrm{~V}$ (SCE) peak $\mathrm{A}_{\mathrm{II}}$, (b) $-0.888 \mathrm{~V}$ (SCE) peak $\mathrm{A}_{\mathrm{III}},(\mathbf{c})+0.10 \mathrm{~V}$ (SCE) passive region and $(\mathbf{d})+0.420 \mathrm{~V}(\mathrm{SCE})$ and at $298 \mathrm{~K}\left(25^{\circ} \mathrm{C}\right)$.

investigated peak potential $\left(\mathrm{A}_{\mathrm{III}}\right)$ is related to the formation of $\mathrm{Ni}(\mathrm{OH})_{2} / \mathrm{NiO}$ on the electrode surface. The data for the same alloy IV treated at $+0.1 \mathrm{~V}$ vs. SCE (passive region; figure $12 \mathrm{c}$ ) reveal that the surface is covered by $\mathrm{ZnO}$ as a major and $\mathrm{NiO}$ or $\mathrm{ZnO}_{2}$ as minor constituents. By comparing the analysis data of both $\mathrm{Ni}$ and $\mathrm{Zn}-\mathrm{Ni}$ alloy $\mathbf{I V}$, it is 

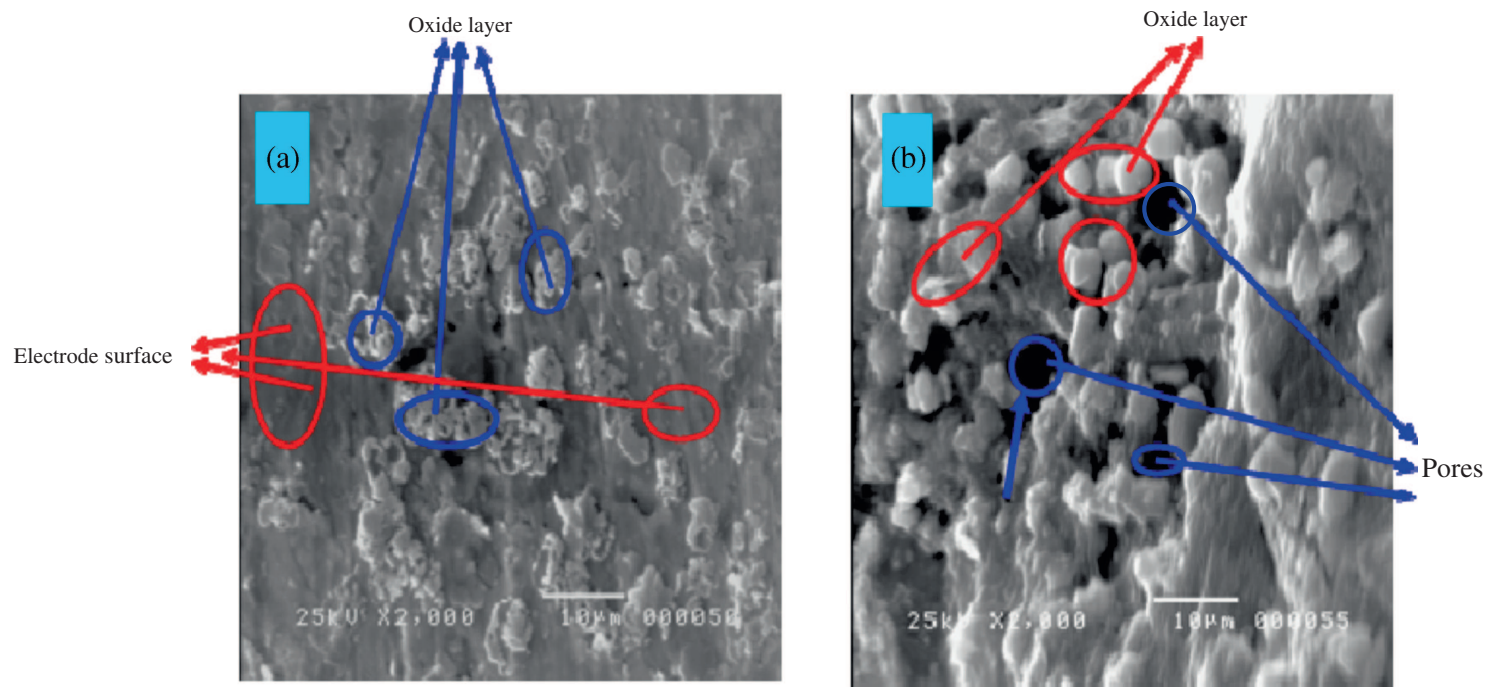

Figure 13. SEM photographs of the corrosion layer on the $\mathrm{Zn}$ surface formed anodically in $0.50 \mathrm{M} \mathrm{KOH}$ solution at (a) $-1.229 \mathrm{~V}$ vs. SCE (peak A II) and (b) $+1.0 \mathrm{~V}(\mathrm{SCE})$.
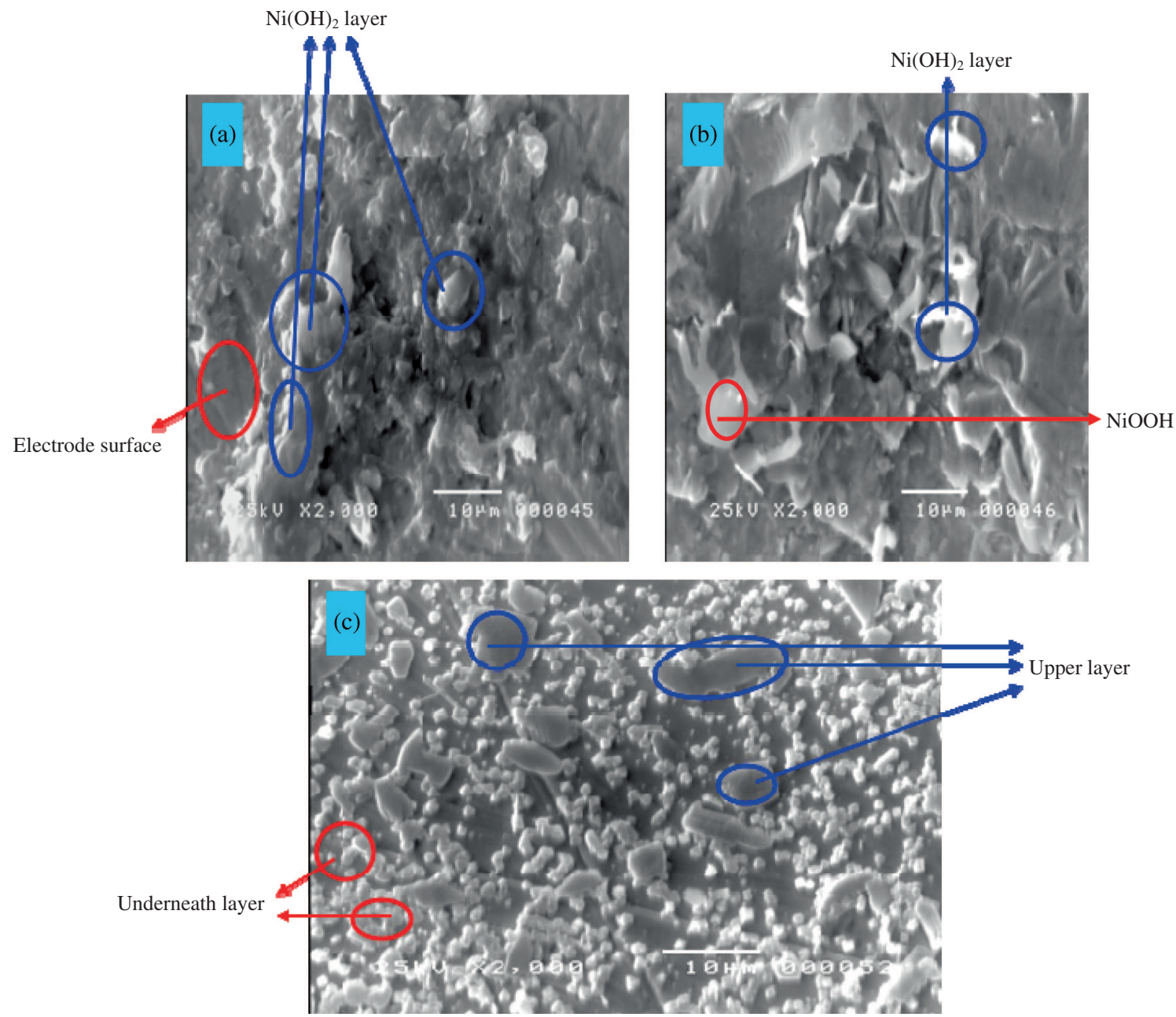

Figure 14. SEM photographs of the corrosion layer on the Ni surface formed anodically in $0.50 \mathrm{M} \mathrm{KOH}$ solution at (a) $-0.209 \mathrm{~V} v$ s. $\mathrm{SCE}\left(\mathrm{A}_{\mathrm{I}}\right),(\mathbf{b})+1.942 \mathrm{~V}$ vs. SCE $\left(\mathrm{A}_{\mathrm{II}}\right)$ and (c) $+3.500 \mathrm{~V}$ vs. SCE (passive). 
observed that $\mathrm{Ni}_{2} \mathrm{O}_{3}$ and $\mathrm{NiOOH}$ are not formed in the case of alloy. This behaviour can be attributed to alloying $\mathrm{Zn}$ with $\mathrm{Ni}$ retards the formation of $\mathrm{NiOOH}$ or $\mathrm{Ni}_{2} \mathrm{O}_{3}$, when the alloy surface is passivated at more positive potential. Figure $12 \mathrm{~d}$ shows XRD data of alloy IV treated at $+0.420 \mathrm{~V} v s$. SCE (at breakdown potential of oxide layer). The data infer that the surface contains $\mathrm{Zn}$ in a large amount and $\mathrm{ZnO}$ and $\mathrm{NiO}$ as minor constituents. Comparison between $\mathrm{X}$-ray data for the presence of $\mathrm{ZnO}$ and $\mathrm{NiO}$ amounts on the surface of the alloy at both $+0.1 \mathrm{~V} v$ s. SCE (less positive potential) and $+0.420 \mathrm{~V} v s$. SCE (more positive potential), reveals that large amounts of $\mathrm{ZnO} / \mathrm{ZnO}_{2}$ and $\mathrm{NiO}$ are formed at less positive potential compared with those amounts formed at more positive potential. This provides that at more positive potential, all $\mathrm{ZnO}_{2}$ and most $\mathrm{NiO}$ dissolve in $\mathrm{KOH}$ solution and leads to reactivation of the electrode surface. ${ }^{58}$ Therefore, XRD results are in good agreement with both potentiodynamic and potentiostatic measurements, in which the current density increases suddenly at the investigated potential $(+0.420 \mathrm{~V} v s$. SCE). 3.3b Microscopic examination: Figure 13a and b shows the micrographs of the corrosion layer formed potentiostatically on surface of $\mathrm{Zn}$ in $0.5 \mathrm{M} \mathrm{KOH}$ solution at applied potentials -1.229 (peak $\mathrm{A}_{\mathrm{II}}$ ) and $+1.0 \mathrm{~V} v s$. SCE. It may appear from figure 13a that the surface is partially covered by the passive film (mixture form $\mathrm{ZnO}$ and $\mathrm{ZnO}_{2}$ ) and the electrode surface may be seen. The oxide patches of the layer exhibit the same shapes. The oxide patches of this layer are not compact, i.e., there are vacancies between them. These observations are in agreement with the data of $\mathrm{XRD}$ that the corrosion layer is related to $\mathrm{ZnO} / \mathrm{ZnO}_{2}$. However, the photograph of $\mathrm{Zn}$ treated anodically at $+1.0 \mathrm{~V} v s$. SCE (passive region; figure 13b), recognized that the surface contains some pores and the oxide patches are smaller and the amount is greater than that at more negative potential (peak $\mathrm{A}_{\text {II }}$ ). The oxide patches of the layer become more adhered on the surface, and are not compact, i.e., there are vacancies between them. Therefore, SEM results support the potentiodynamic measurements that high current density in the passive region is obtained. This behaviour may be

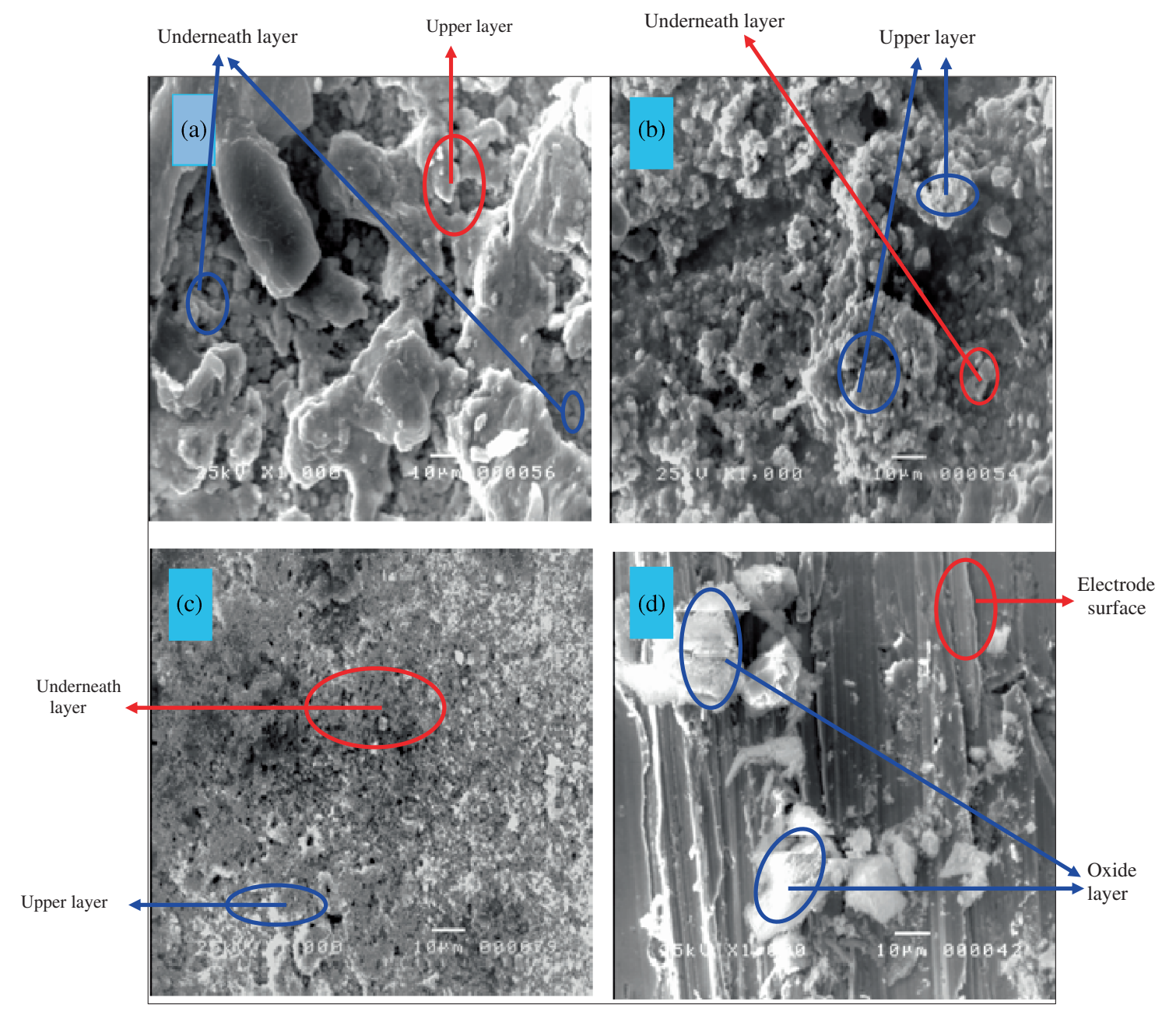

Figure 15. SEM photographs of the corrosion layer on alloy IV surface formed anodically in $0.50 \mathrm{M}$ KOH solution at (a) $-1.20 \mathrm{~V} v s$. SCE (peak $\left.\mathrm{A}_{\mathrm{II}}\right),(\mathbf{b})-0.888 \mathrm{~V} v s$. SCE (peak $\left.\mathrm{A}_{\mathrm{III}}\right),(\mathbf{c})+0.10 \mathrm{~V} v$ s. SCE (passive) and (d) $+0.42 \mathrm{~V}$ vs. SCE. 
due to an amount from this layer dissolved in the bulk of solution.

Figure $14 \mathrm{a}-\mathrm{c}$ shows the micrographs of the corrosion layer formed potentiostatically on surface of $\mathrm{Ni}$ in $0.5 \mathrm{M}$ $\mathrm{KOH}$ solution at applied potentials $-0.209,+1.942$ and $+3.50 \mathrm{~V}$ vs. SCE. It may appear from figure 14a (Peak $\mathrm{A}_{\mathrm{I}}$ ) that the surface is partially covered by the passive film. One layer is observed on the electrode surface. The oxide patches of the layer exhibited different shapes. The oxide patches of this layer are not compact, i.e., there are vacancies between them. These observations are in agreement with the data of XRD that the layer is related to $\mathrm{Ni}(\mathrm{OH})_{2}$. Figure $14(\mathrm{~b})$ shows SEM photographs of $\mathrm{Ni}$ treated at $+1.942 \mathrm{~V} v s$. $\mathrm{SCE}$, it is found that the surface is almost completely covered by the corrosion layer. The oxide patches exhibit different shapes. Therefore, the electrode surface seems to be completely covered by $\mathrm{NiOOH}$ with $\mathrm{Ni}(\mathrm{OH})_{2}$, and this is suggested by XRD. However, at higher potential $+3.50 \mathrm{~V} v s$. SCE (passive region; figure 14c), it is observed that the most of the surface is covered by some oxide patches. Two layers are observed on the electrode surface. The oxide patches of the upper layer exhibited small amounts may be $\mathrm{Ni}_{2} \mathrm{O}_{3}$, and the amount of underneath layer is increased and the distance between them becomes less widely compared with those in figure 14b. These observations are in agreement with the data of XRD that, the surface contains a mixture of oxides $\left(\mathrm{Ni}_{2} \mathrm{O}_{3}\right.$, $\mathrm{NiO}$ and $\mathrm{NiOOH})$.

Figure 15a-d shows the micrographs of the corrosion layer formed potentiostatically on surface of alloy IV in $0.5 \mathrm{M}$ solution of $\mathrm{KOH}$ at applied potentials $-1.20,-0.888,+0.10$ and $+0.42 \mathrm{~V} v s$. SCE. It would be recognized from figure $15 \mathrm{a}$ that the treated surface at $-1.20 \mathrm{~V}$ vs. SCE (peak $\mathrm{A}_{\mathrm{II}}$ ) is covered by the passive layer. Two layers are observed on the electrode surface, and its oxide patches exhibited different shapes compared with those of pure zinc (peak $A_{I I}$ ). However, the higher corrosion resistance of the alloy leads to lower current density of peak $\mathrm{A}_{\mathrm{II}}$ than that of pure $\mathrm{Zn}$. Figure 15b shows SEM photographs of the same alloy treated at $-0.888 \mathrm{~V}$ vs. SCE (peak $\mathrm{A}_{\mathrm{III}}$ ). It is found that the surface is almost completely covered by adhered passive oxides. Two layers are observed on the electrode surface. The oxide patches of the upper layer exhibited similar shapes. The second layer seems to lie below the upper layer and their oxide patches size is smaller. These observations are in agreement with the data of XRD that, the upper layer is related to $\mathrm{ZnO} / \mathrm{ZnO}_{2}$, while the underneath layer is due to $\mathrm{Ni}(\mathrm{OH})_{2}$ or $\mathrm{NiO}$ formation. For the electrode surface treated anodically at $+1.0 \mathrm{~V}$ vs. SCE (more positive potential; figure 15c), it appears two layers of the oxide patches on the alloy surface (double nature). It is observed that the amount of the oxide patches at the upper layer decreases and becomes more distant apart than those in figure $15 \mathrm{~b}$, the quantity of the oxide patches in the underneath layer increases with smaller size. Whereas the oxide patches of the upper layer become loosely bound to the alloy surface, and an amount from this layer dissolves in the bulk of the solution. In addition the oxide patches of the underneath layer are dispersed on the whole surface. Figure 15d shows SEM photographs of alloy IV treated at $+0.42 \mathrm{~V} v s$. SCE (at the breakdown potential of oxide layer). The data show that the oxide film formed on the alloy surface is less than that formed at more positive potential (figure 15c). Thus some parts of the alloy surface can be seen. Therefore, SEM results are in good agreement with both potentiodynamic and potentiostatic measurements, in which the current density increases suddenly at the investigated potential $(+0.42 \mathrm{~V}$ vs. SCE).

\section{Conclusions}

Potentiodynamic oxidation of $\mathrm{Zn}$ and its investigated alloys exhibits active/pseudopassive transition state, while $\mathrm{Ni}$ exhibits active/passive one in various concentrations of $\mathrm{KOH}$ solution. The active dissolution of $\mathrm{Zn}, \mathrm{Ni}$ and their alloys increases with the increase of both concentration of $\mathrm{KOH}$ and temperature. However, the results show that the increase in $\mathrm{Ni}$ content in the alloy decreases the dissolution rate in $\mathrm{KOH}$ solution, consequently the maximum corrosion resistance is obtained at $10 \% \mathrm{Ni}$ content (alloy IV). Passivation of zinc is due to precipitation of a thin film of $\mathrm{ZnO}$ and $\mathrm{ZnO}_{2}$. However, passivation of $\mathrm{Ni}$ is due to the formation of thick film from $\mathrm{NiOOH}, \mathrm{NiO}$ and $\mathrm{Ni}_{2} \mathrm{O}_{3}$ on the electrode surface. Passivation of $\mathrm{Zn}-\mathrm{Ni}$ alloys can be attributed to the formation of a thin film from $\mathrm{ZnO}, \mathrm{ZnO}_{2}$ and $\mathrm{NiO}$. It is observed that $\mathrm{Ni}_{2} \mathrm{O}_{3}$ and $\mathrm{NiOOH}$ are not formed on the alloy surface. The results show that the corrosion resistance of $\mathrm{Zn}-\mathrm{Ni}$ alloy is superior to that of $\mathrm{Zn}$ in alkaline solutions. The results of both potentiodynamic and potentiostatic measurements exhibit sudden increase in current density which is observed at certain positive potential $(+0.42 \mathrm{~V}$ vs. SCE) in the case of the investigated alloys. This indicates that the addition of $\mathrm{Ni}$ to $\mathrm{Zn}$ promotes the electrochemical reaction (in the passive region). Therefore $\mathrm{Zn}-\mathrm{Ni}$ alloy can be used as anodes in the alkaline batteries due to its high corrosion resistance and reactivation of the alloy surface in the passive region. The values of activation energy $\left(E_{\mathrm{a}}\right)$ at both peak and passivation current densities gradually increase with the increase in Ni content in the alloy, and the maximum value is obtained in the case of alloy IV $(10 \% \mathrm{Ni})$. This observed higher energy barrier would be attributed to the hindrance of dissolution process by increasing Ni content in the alloy.

\section{References}

1. Dobryszycki J and Biallozor S 2001 Corros. Sci. 431309

2. Baugh L M and Baikie A R 1985 Electrochim. Acta 301173

3. Baugh L M and Higginson A 1985 Electrochim. Acta 301163

4. Biallozor S and Dobryszycki J, Proc Eurocorr'98, Utrecht, Holland, 28 September-1 October 1998

5. Bockris J O' M, Nagy Z and Damjanovic A 1972 J. Electrochem. Soc. 119285

6. Brodd R J and Leger V E, in: Bard A J (ed), Encyclopedia of electrochemistry of the elements (New York: Marcel Dekker) vol. 5 (Chapter V-1) 1974 
7. Cabot P L I, Cortes M, Centellas F A, Garrido J A and Perez E 1987 Electrochim. Acta 321321

8. Cachet C, Saidani B and Wiart R 1992 J. Electrochem. Soc. 139644

9. Cai M and Park S M 1996a J. Electrochem. Soc. 1432125

10. Cai M and Park S M 1996b Electrochim. Acta 1433895

11. Chang Y C and Prentice G A 1989 Electrochim. Acta 136 3398

12. Chang Y C and Prentice G A 1984 Electrochim. Acta 1311465

13. Cyrankowska M and Szczesniak B 1994 Prog. Batteries Battery Mater. 3233

14. Dirkse T P and Hampson N A 1972 Electrochim. Acta 171113

15. Hutchison P F and Turner J 1976 J. Electrochem. Soc. 123185

16. Kannan A R S, Muralidharan S, Sarangapani K B, Balaramachandran V and Kapali V 1995 J. Power Sources 5793

17. Keily T and Sinclair T J 1981 J. Power Sources 647

18. Maja M, Penazzi N, Farnia G and Sandona G 1993 Electrochim. Acta 381453

19. Mansfeld F and Gilman S 1970 J. Electrochem. Soc. 117 1328

20. Müller B and Imblo G 1996 Corros. Sci. 38293

21. Nartey V K, Binder L and Kordesch K 1994 J. Power Sources 52217

22. Scholl P, Shan X, Bonham D and Prentice G A 1991 Electrochim. Acta 138895

23. Singh D D N and Banerjee M K 1986 Corros. NACE 42156

24. Abd El Aal E E 2003a Corros. Sci. 45641

25. Abd El Aal E E 2003b Corros. Sci. 45759

26. Chao C and Szklarska-Smialowska Z 1980 Surf. Sci. 96426

27. MacDougall B and Cohen M 1976 J. Elecrochem. Soc. 123191

28. Okuyama M and Haruyama S 1974 Corros. Sci. 141

29. Ord J L, Clayton J C and DeSmet D J 1977 J. Electrochem. Soc. 1241754

30. Paik W and Szklarska-Smialowska Z 1980 Surf. Sci. 96401

31. Sato N and Kudo K 1974 Electrochim. Acta 19461

32. Seghiouer A, Chevalet J, Barhoun A and Lantelme F $1998 J$. Electroanal. Chem. $\mathbf{4 2 2} 113$

33. Vissker W and Barendrecht E 1983 Surf. Sci. 135436

34. Barcelō G, Garcia E, Sarret M and Mūller C 1998 J. Appl. Electrochem. 281113
35. Elhajjami A, Gigandet M P, De Petris-Wery M, Catonne J C, Duprat J J, Thiery L, Raulin F, Starck B and Remy P 2008 Appl. Surf. Sci. 2551654

36. Heydarzadeh Sohi M and Jalali M 2003 J. Mater. Process. Technol. 13863

37. Hotellaz B, Bonino J P and Rousset A 1999 J. Mater. Sci. 34 881

38. Lin C-C and Huang C-M 2006 JCT Res. 993

39. Petrauskas A V, Grintsyavichene L S, Cheshunene A V and Matulenis E L 2003 Prot. Met. 39454

40. El-Sayed A, Mohran H S and Abd-Elateef H M 2011 Metall. Mater. Trans. A online: 6 October 2011

41. Okamoto H 2003 J. Phase Equilibria 24280

42. Abd El Rehim S S, Hassan H H and Mohamed N F 2004 Corros. Sci. 461071

43. Amin M A 2005 Electrochim. Acta 501265

44. Shams El Din A M, Abd El Wahaab F M and Abd El Haleem S M 1973 Werkst. Korros. 24389

45. Popova T I, Bagotskii V S and Kabanov B N 1992 Russ. J. Phys. Chem. 36770

46. Abd El Aal E E 1999 Corros. NACE 55582

47. Abd El Aal E E and Abd El-Haleem S M 2005 Chem. Eng. Technol. 281158

48. Uno S F 1960 J. Elecrochem. Soc. 107661

49. Mohran H S, El-Sayed A and Abd El-Lateef H M 2009 J. Solid State Electrochem. 131279

50. El-Sayed A, Shaker A M and Gad El-Kareem H 2003 Bull. Chem. Soc. Jpn. 761527

51. Wilcox G D and Gabe D R 1993 Corros. Sci. 351251

52. Foad El-Sherbini E E and Abd El Rehim S S 2000 Corros. Sci. 42785

53. Hassan H H, Abd El-Rehim S S and Mohamed N F 2002 Corros. Sci. 4437

54. Refaey S A M, Taha F and Hasanin T H A 2006 Electrochim. Acta $\mathbf{5 1} 2942$

55. Sato N and Okamoto G 1963 J. Electrochem. Soc. 110605

56. Xu J, Liu X, Li X, Barbero E and Dong C 2006 J. Power Sources 155420

57. Badawy A W, Ismail K M and Fathi A M 2005 Electrochim. Acta $\mathbf{5 0} 3603$

58. El-Sayed A, Mohran H S and Abd El-Lateef H M $2010 \mathrm{~J}$. Power Sources 1956924 